\title{
Increased Hospitalizations for Ischemic Stroke with Comorbid Diabetes and Residential Proximity to Sources of Organic Pollutants: A 12-Year Population-Based Study
}

\author{
Alexander V. Sergeev ${ }^{a}$ David O. Carpenter ${ }^{b}$ \\ ${ }^{a}$ School of Public Health Sciences and Professions, Ohio University, Athens, Ohio, and ${ }^{\mathrm{b}}$ Institute for Health and \\ the Environment, University at Albany, Rensselaer, N.Y., USA
}

\section{Key Words}

Ischemic stroke, epidemiology $\cdot$ Risk factors $\cdot$ Diabetes

mellitus · Environmental factors

\begin{abstract}
Background: Evidence is emerging that exposure to persistent organic pollutants (POP) is a risk factor for atherosclerosis-related diseases and for diabetes mellitus (DM). We hypothesized that residential proximity to sources of POP will be associated with an increase in hospitalization rates for ischemic stroke (IS) with comorbid DM (IS-DM). Methods: We examined IS-DM hospitalization rates in the New York State (exclusive of New York City) during a 12-year period. POP exposure status was assessed based on residency in a zip code containing or abutting environmental sources of POP. Adjusted relative risks (RR) of IS-DM hospitalization were estimated by multivariate Poisson regression. Results: A statistically significant $10 \%$ increase in IS-DM hospitalization rates was observed in populations environmentally exposed to POP (adjusted RR 1.10, 95\% confidence interval, Cl, 1.01-1.20; $p=0.031$ ). IS-DM hospitalization rates were also higher in males (adjusted RR 1.34, 95\% Cl 1.30-1.39; $\mathrm{p}<$ 0.001), in blacks (adjusted RR 4.54, 95\% Cl 4.16-4.94; $p<$ 0.001 ) and in older age groups ( $p$ for trend $<0.001$ ). Conclu-
\end{abstract}

sions: Residential proximity to sources of POP is associated with an increase in RR of IS-DM hospitalization. Our findings support the hypothesis of POP being a risk factor for IS. Further studies are warranted.

Copyright $\odot 2010$ S. Karger AG, Basel

\section{Introduction}

Cerebrovascular disease is the second leading cause of death, causing about 5.7 million annual deaths worldwide [1]. Ischemic strokes (IS) account for $87 \%$ of all strokes [2]. Diabetes mellitus (DM) is not only a well-established risk factor for stroke [2, 3], but also a predictor of poor outcome of IS [4], making the combination of IS with DM as a comorbidity (IS-DM) particularly dangerous. DM is highly prevalent among stroke patients, but often remains unrecognized until hospitalization $[5,6]$.

Up to $20 \%$ of atherosclerotic IS cases are not explained by traditional risk factors for atherosclerosis, such as diabetes, hypertension, hypercholesterolemia and smoking [7]. Evidence from a number of epidemiological and experimental animal studies indicates that exposure to persistent organic pollutants (POP) is an important risk factor both for atherosclerosis-related diseases [8-10], in-

\section{KARGER}

() 2010 S. Karger AG, Basel

Fax +4161306 1234 E-Mail karger@karger.ch www.karger.com www.karger.com/ned
Alexander V. Sergeev, MD, PhD, MPH

School of Public Health Sciences and Professions

Ohio University, Grover Center E329

Athens, $\mathrm{OH} 45701$ (USA)

Tel. +1 740593 0635, Fax +1 740593 0555, E-Mail sergeev@ ohio.edu 
cluding stroke [11], and for DM [12-14]. POP constitute a group of polychlorinated organic compounds, including polychlorinated biphenyls, persistent pesticides, such as dichlorodiphenyltrichloroethane, and dioxins and $\mathrm{fu}$ rans. They are characterized by semivolatility and high resistance to biological, chemical and photolytic degradation [15]. Due to their lipophilicity, POP can bioaccumulate in lipid-rich tissues, including the liver, the nervous tissue and the adipose tissue $[16,17]$. We hypothesized that residential proximity to sources of POP will be associated with an increase in IS-DM hospitalization rates.

\section{Materials and Methods}

\section{Study Population}

We conducted a population-based study of hospitalization rates for IS-DM in New York State excluding New York City. ISDM hospitalization data for a 12-year period (1993-2004) were obtained from the New York Statewide Planning and Research Cooperative System maintained by the New York State Department of Health. Along with patients' age, race, gender and zip code of residence, we used information on the principal and up to 14 secondary diagnoses which is mandatory reporting on every hospitalized patient. To identify IS, we used the International Classification of Diseases, 9th revision (ICD-9), codes 433.x1, 434.x1 and 436, which have been shown to identify IS patients accurately $[18,19]$. ICD- 9 code 250 was used to identify comorbid type 1 or type $2 \mathrm{DM}$.

The primary outcome variable was the rate of hospitalizations for IS with comorbid DM by zip code of residence. Demographic information on the total population, including age, gender and race, was used to adjust for confounding by these variables. $\mathrm{Me}$ dian household income on the zip code level, obtained from Claritas Inc. (San Diego, Calif., USA), was used as a measure of socioeconomic status [20]. Because lower socioeconomic status is a known barrier to health care utilization [21], we included only the 3 upper quartiles of the medium-household income distribution.

We included only patients of the 2 largest racial groups - African Americans (blacks) and Caucasians (whites) - that comprised a total of $98.6 \%$ of IS-DM hospitalizations. Other racial groups were not included in the study due to their extremely small numbers that can compromise the parsimony of the statistical model. The upper age limit was set at 74 years inclusive, because for atherosclerosis-related diseases, including stroke, the effect of age becomes very strong in older age groups to the extent that it can obscure the effect of other risk factors. The effect of DM as an IS risk factor is particularly prominent in patients younger than 65 years [5].

Exposure status was classified as POP or no-POP based on the patients' zip codes of residence. Patients residing in zip codes containing or abutting hazardous waste sites contaminated with POP were presumed to be environmentally exposed. Most of the POP the patients were exposed to were polychlorinated biphenyls (75.7\%). Other POP were dichlorodiphenyldichloroethane, dichlorodiphenyltrichloroethane, chlordane, dieldrin, endosulfan, endrin, hexachlorobenzene, heptachlor, pyranol, pesticides and herbicides. Zip codes containing or abutting environmental sources of POP were identified using the National Priority List of the hazardous waste sites (as determined by the US Environmental Protection Agency) and the list of the State Superfund sites (as determined by the New York State Department of Environmental Conservation). Also, polluted portions of the Great Lakes and St. Lawrence River known as Areas of Concern were identified by the International Joint Commission. Details of these classifications have been previously described somewhere else [22]. Exclusive of New York City, there were 196 zip codes in New York State classified as POP and 1,207 as no-POP. Of the 1,207 no-POP zip codes, 215 contained known waste sites having other than POP pollutants (such as metals), and 992 did not contain any known environmental source of pollutants.

The study was approved by the Institutional Review Boards of Ohio University and University at Albany.

\section{Statistical Analyses}

In preliminary unadjusted analyses, IS-DM hospitalization rates were compared separately for each population group by a presumed exposure status (residential proximity to sources of POP), gender, race and age. Bonferroni correction was applied to multiple comparisons. The Wald statistic was used to assess the significance of age trend. Relative risks (RR) for IS-DM hospitalization were calculated as hospitalization rate ratios.

In adjusted analysis, RR and their respective 95\% confidence intervals (CI) were obtained by using multivariate Poisson regression. Confounding by gender, race and age was adjusted for by including the respective variables in the multivariate Poisson regression model. Overdispersion in the multivariate Poisson regression model was adjusted for by using a scaling factor; the scaled Pearson $\chi^{2}$ was equal to 1 . We also adjusted for clustering of observations within zip codes by using the generalized estimating equations method. SAS software, version 9.1 (SAS Institute Inc., Cary, N.C., USA), was used for statistical analyses.

\section{Results}

\section{Patient Characteristics}

We identified a total of 19,502 hospital admissions for IS-DM from 1993 to 2004. Residents of the POP zip codes constituted $24.3 \%$ of the population from which IS-DM cases were ascertained, but they accounted for $27.9 \%$ of admissions (5,440 cases). Males comprised $53.8 \%$ of ISDM admissions (10,493 cases). The mean \pm SD age of the patients was $64.3 \pm 8.3$ years. Although blacks comprised only $6.7 \%$ of the study population from which cases were ascertained, they accounted for $15.2 \%$ of IS-DM admissions (2,973 cases), which indicates that African American race is a risk factor for stroke and diabetes.

\section{Unadjusted Analyses}

Unadjusted analysis of IS-DM hospitalization rates in POP and no-POP groups demonstrated that residency in a zip code containing or abutting environmental sources 
Table 1. Unadjusted IS-DM hospitalization rates and unadjusted RR of IS-DM hospitalization

\begin{tabular}{llccc}
\hline Characteristic & & $\begin{array}{l}\text { Unadjusted IS-DM } \\
\text { hospitalization rates } \\
\text { n/100,000 person-years }\end{array}$ & Unadjusted RR \\
& & $34.22(33.31-35.12)$ & $1.21(1.17-1.25)$ \\
value \\
Exposure status & POP & $28.34(27.87-28.81)$ & 1.0 & $<.24(1.20-1.27)$ \\
Nonder & Males & $33.00(32.37-33.63)$ & 1.0 \\
Race & Females (ref.) & $26.71(26.16-27.27)$ & $2.67(2.57-2.77)$ \\
Age & Blacks & $81.85(69.27-74.43)$ & 1.0 \\
& Whites (ref.) & $26.93(26.52-27.34)$ & $6.82(5.34-69.23)$ \\
& & & $39.69(31.54-53.26)$ \\
& $35-44$ years & $2.63(2.39-2.87)$ & $137.61(109.64-184.39)$ \\
& $45-54$ years & $15.30(14.65-15.94)$ & $353.47(281.87-473.42)$ \\
\end{tabular}

Figures in parentheses indicate $95 \%$ CI. ${ }^{1} \mathrm{p}$ value for trend, Wald statistic.

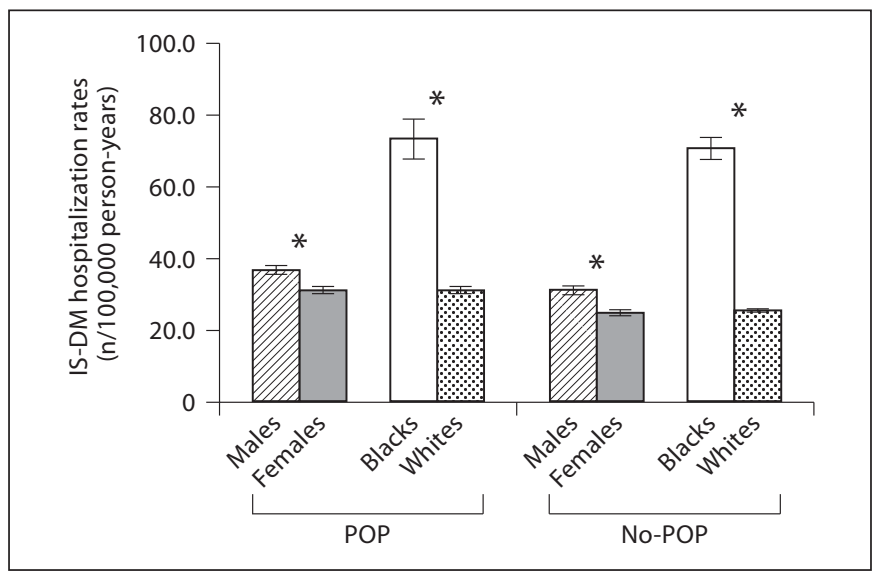

Fig. 1. Unadjusted IS-DM hospitalization rates with $95 \% \mathrm{CI}$ indicated by vertical bars: gender and race, stratified by POP exposure status. ${ }^{*} \mathrm{p}<0.01$, with Bonferroni correction.

of POP is associated with a $21 \%$ increase in RR of IS-DM hospitalization (unadjusted RR 1.21, 95\% CI 1.17-1.25; table 1). Also, unadjusted analyses indicated that RR of IS-DM hospitalization is higher in males than females, in blacks than in whites, and in older age groups. Results of unadjusted stratified analyses, stratified by the POP exposure status, are presented in figures 1 and 2 . Being male, African American and older were associated with higher RR of IS-DM hospitalization in residents of both POP and no-POP zip codes.

\section{Adjusted Analyses}

Results of the adjusted analysis (table 2) demonstrated that after controlling for the effect of known confounders (race, gender and age), residency in POP zip codes is associated with a statistically significant $10 \%$ increase in IS-DM hospitalization rates (adjusted RR 1.10, 95\% CI $1.01-1.20, \mathrm{p}=0.031$ ). Also, adjusted analysis demonstrated, as expected, that African American race, male gender and older age are associated with a statistically significant increase in IS-DM hospitalization rates. While it was not a primary goal of our study, we also investigated the relationship between POP exposure status and RR of hospitalization for IS only (without DM comorbidity): residency in POP zip codes was associated with a statistically significant $9 \%$ increase in IS-only hospitalization rates (adjusted RR 1.09, 95\% CI 1.02-1.17, p = 0.016; table 3).

\section{Discussion}

Residential proximity to environmental sources of POP is associated with a statistically significant $10 \%$ increase in IS-DM hospitalization rates $(\mathrm{p}=0.031)$. Given a high worldwide burden of stroke fatality and disability $[23,24]$, it is imperative to investigate emerging risk factors to better understand the distribution and determinants of disease and to improve effectiveness of existing prevention strategies. Environmental risk factors are of particular concern because they are involuntary and can 
Fig. 2. Unadjusted IS-DM hospitalization rates with $95 \% \mathrm{CI}$ indicated by vertical bars: age, stratified by POP exposure status. ${ }^{*} \mathrm{p}$ for trend $<0.01$, with Bonferroni correction.

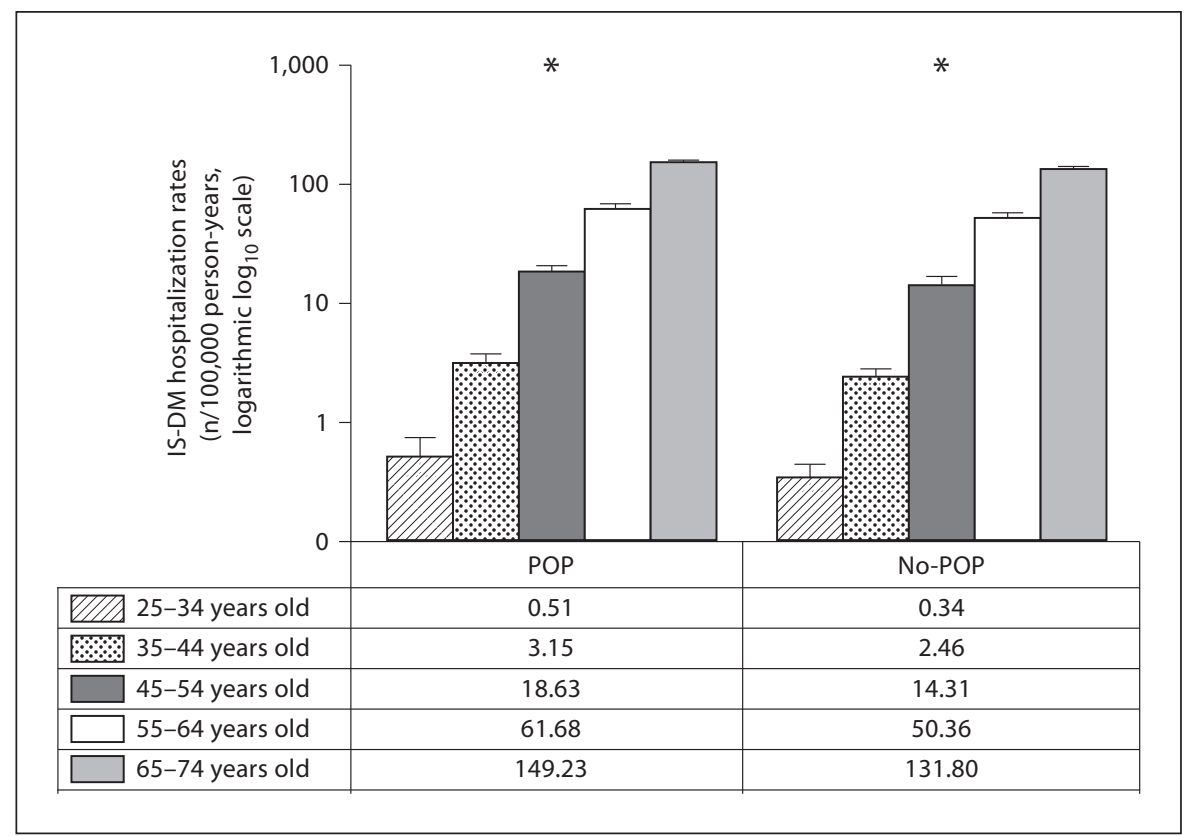

affect large population groups. Residential proximity to POP-contaminated waste sites is associated with an increase in POP serum levels [25].

The results of our study are consistent with existing evidence that POP are a risk factor for atherosclerosisrelated diseases and DM. It should be noted that exposure to POP is not the only risk factor which can be linked to a number of diseases and health conditions. Another well-known example of such an exposure is smoking, an established risk factor for atherosclerosis-related diseases, chronic obstructive pulmonary disease, and a number of malignancies, including lung and oral cancer.

Other authors reported an increase in coronary heart disease morbidity and mortality in populations exposed to dioxins $[9,26,27]$ and demonstrated a dose-response gradient for coronary heart disease mortality [28]. Exposure to POP is associated with atherogenic dyslipidemias [29] and development of detectable atherosclerotic lesions in arteries [30]. Results of human studies indicate that the leading mechanism responsible for the atherogenic effect of POP is their interference with lipid metabolism in the liver that promotes development of atherogenic dyslipidemias. Animal studies have provided evidence supporting this observation $[10,31]$. Other plausible mechanisms of the atherogenic effect of POP include oxidative stress-mediated direct damage to endothelial cells and inflammation $[32,33]$.

Several epidemiological and animal studies have demonstrated a strong association between exposure to POP and risk of type 1 and type $2 \mathrm{DM}[13,14,34]$. The most likely mechanism is gene expression dysregulation [33$35]$ leading to impaired glucose transport and $\beta$-cell insulin depletion.

We investigated the association between residential proximity to POP and hospitalization rates for IS with comorbid DM for a reason. DM is not only a risk factor for IS, but it also worsens prognosis for IS patients [4]. This makes exposure to POP, as a risk factor for both IS and $\mathrm{DM}$, particularly harmful and alarming from the public health perspective. A previous study from our group has shown that residential proximity to POP is associated with an increased risk of hospitalization for DM [35].

As expected, the adjusted analysis demonstrated a statistically significant positive association of IS-DM hospitalization rates with African American race, male gender and older age. While investigation of these associations was not a primary goal of our study, they are consistent with the current knowledge of well-established stroke risk factors and thus serve as indirect quality indicators for our adjusted analysis model proving its biological plausibility.

Our study is not free from limitations. Information on hospital discharges from federally regulated facilities, such as those operated by the US Department of Veterans Affairs, was not available, nor was information on some risk factors, such as smoking and diet. Our study's correlational data are not sufficient to draw an ultimate 
Table 2. Adjusted RR of IS-DM hospitalization in relation to environmental POP exposure status and demographic characteristics

\begin{tabular}{|c|c|c|c|c|}
\hline Parameter & $\beta$-Coefficient & Standard error & Adjusted RR & $\mathrm{p}$ value \\
\hline POP (compared to no-POP) ${ }^{1}$ & 0.096 & 0.045 & $1.10(1.01-1.20)$ & 0.031 \\
\hline Males (compared to females) ${ }^{2}$ & 0.295 & 0.018 & $1.34(1.30-1.39)$ & $<0.001$ \\
\hline Blacks (compared to whites) ${ }^{3}$ & 1.512 & 0.044 & $4.54(4.16-4.94)$ & $<0.001$ \\
\hline Age (compared to $25-34$ years old $)^{4}$ & & & & $<0.001^{5}$ \\
\hline $35-44$ years & 0.326 & 0.143 & $1.39(1.05-1.83)$ & \\
\hline $45-54$ years & 1.377 & 0.141 & $3.96(3.01-5.22)$ & \\
\hline $55-64$ years & 2.439 & 0.141 & $11.46(8.69-15.11)$ & \\
\hline $65-74$ years & 3.368 & 0.140 & $29.02(22.04-38.22)$ & \\
\hline
\end{tabular}

Figures in parentheses indicate 95\% CI. ${ }^{1}$ Adjusted for gender, race and age. ${ }^{2}$ Adjusted for exposure status, race and age. ${ }^{3}$ Adjusted for exposure status, gender and age. ${ }^{4}$ Adjusted for exposure status, gender, and race. ${ }^{5} \mathrm{p}$ value for trend, Wald statistic.

Table 3. Adjusted RR of IS-only (without DM comorbidity) hospitalization in relation to environmental POP exposure status and demographic characteristics

\begin{tabular}{|c|c|c|c|c|}
\hline Parameter & $\beta$-Coefficient & Standard error & Adjusted RR & $\mathrm{p}$ value \\
\hline POP (compared to no-POP) ${ }^{1}$ & 0.085 & 0.035 & $1.09(1.02-1.17)$ & 0.016 \\
\hline Males (compared to females) ${ }^{2}$ & 0.364 & 0.013 & $1.44(1.40-1.48)$ & $<0.001$ \\
\hline Blacks (compared to whites) ${ }^{3}$ & 1.040 & 0.044 & $2.83(2.60-3.09)$ & $<0.001$ \\
\hline Age (compared to $25-34$ years old $)^{4}$ & & & & $<0.001^{5}$ \\
\hline $35-44$ years & 0.621 & 0.064 & $1.86(1.64-2.11)$ & \\
\hline $45-54$ years & 1.571 & 0.073 & $4.81(4.17-5.56)$ & \\
\hline $55-64$ years & 2.517 & 0.074 & $12.39(10.72-14.32)$ & \\
\hline $65-74$ years & 3.520 & 0.074 & $33.79(29.23-39.06)$ & \\
\hline
\end{tabular}

Figures in parentheses indicate $95 \%$ CI. ${ }^{1}$ Adjusted for gender, race and age. ${ }^{2}$ Adjusted for exposure status, race and age. ${ }^{3}$ Adjusted for exposure status, gender and age. ${ }^{4}$ Adjusted for exposure status, gender and race. ${ }^{5} \mathrm{p}$ value for trend, Wald statistic.

cause-effect conclusion. Zip code of residence is a crude measure of residential proximity to the environmental sources of POP; individual-level information on the exposure status would be helpful, but was unavailable in this study. However, a nondifferential misclassification of exposure status can cause bias towards the null resulting in underestimation of the obtained RR. Thus, if residential proximity had been measured more precisely, we would likely have found an even stronger association between living near POP-contaminated waste sites and the increase in IS-DM hospitalization rates.

In conclusion, the present study of 19,502 IS-DM hospitalizations has demonstrated that residential proximity to the environmental sources of POP is associated with a statistically significant increase in IS-DM hospitalization rates. Our findings support the growing body of evidence of POP being an important risk factor for atherosclerosis- related diseases. Given the involuntary nature of residential exposure to POP, our results not only provide an additional insight into determinants of the disease frequency in populations, but also carry implications for public health approaches aiming to reduce the incidence and burden of cerebrovascular disease. Further studies investigating pathophysiological mechanisms of the atherogenic effect of POP are warranted.

\section{Acknowledgements}

This study was supported by the Ohio University Research Challenge Award (to A.V.S.) and a grant from the Fogarty International Center, National Institutes of Health (TW000636, to D.O.C.), with additional support from the Institute for Health and the Environment (to D.O.C.). We thank Robbie Huang for assistance with the demographics data. 


\section{References}

1 World Health Organization: The Global Burden of Disease: 2004 Update. Geneva, WHO Press, 2008.

$\checkmark 2$ Lloyd-Jones D, Adams RJ, Brown TM, Carnethon M, Dai S, De Simone G, Ferguson TB, Ford E, Furie K, Gillespie C, Go A, Greenlund K, Haase N, Hailpern S, Ho PM, Howard V, Kissela B, Kittner S, Lackland D, Lisabeth L, Marelli A, McDermott MM, Meigs J, Mozaffarian D, Mussolino M, Nichol G, Roger V, Rosamond W, Sacco R, Sorlie P, Stafford R, Thom T, Wasserthiel-Smoller S, Wong ND, Wylie-Rosett J: Heart disease and stroke statistics - 2010 update. A report from the American Heart Association. Circulation 2010;121:e1-e170.

-3 Goldstein LB, Adams R, Alberts MJ, Appel LJ, Brass LM, Bushnell CD, Culebras A, De Graba TJ, Gorelick PB, Guyton JR, Hart RG, Howard G, Kelly-Hayes M, Nixon JV, Sacco RL: Primary prevention of ischemic stroke: a guideline from the American Heart Association/American Stroke Association Stroke Council. Circulation 2006;113:e873-923.

4 Hankey GJ, Spiesser J, Hakimi Z, Bego G, Carita P, Gabriel S: Rate, degree, and predictors of recovery from disability following ischemic stroke. Neurology 2007;68:1583-1587.

5 Kissela BM, Khoury J, Kleindorfer D, Woo D, Schneider A, Alwell K, Miller R, Ewing I, Moomaw CJ, Szaflarski JP, Gebel J, Shukla R, Broderick JP: Epidemiology of ischemic stroke in patients with diabetes: the greater Cincinnati/Northern Kentucky Stroke Study. Diabetes Care 2005;28:355-359.

6 Gray CS, Scott JF, French JM, Alberti KG, O'Connell JE: Prevalence and prediction of unrecognised diabetes mellitus and impaired glucose tolerance following acute stroke. Age Ageing 2004;33:71-77.

7 Hankey GJ: Potential new risk factors for ischemic stroke: what is their potential? Stroke 2006;37:2181-2188.

$\checkmark 8 \mathrm{Ha} \mathrm{MH}$, Lee DH, Jacobs DR: Association between serum concentrations of persistent organic pollutants and self-reported cardiovascular disease prevalence: results from the National Health and Nutrition Examination Survey, 1999-2002. Environ Health Perspect 2007;115:1204-1209.

-9 Kang HK, Dalager NA, Needham LL, Patterson DG Jr, Lees PS, Yates K, Matanoski GM: Health status of Army Chemical Corps Vietnam veterans who sprayed defoliant in Vietnam. Am J Ind Med 2006;49:875-884.

10 Lind PM, Orberg J, Edlund UB, Sjoblom L, Lind L: The dioxin-like pollutant PCB 126 $\left(3,3^{\prime}, 4,4^{\prime}, 5\right.$-pentachlorobiphenyl) affects risk factors for cardiovascular disease in female rats. Toxicol Lett 2004;150:293-299.

11 Shcherbatykh I, Huang X, Lessner L, Carpenter DO: Hazardous waste sites and stroke in New York State. Environ Health 2005;4: 18.
12 Fujiyoshi PT, Michalek JE, Matsumura F: Molecular epidemiologic evidence for diabetogenic effects of dioxin exposure in US air force veterans of the Vietnam war. Environ Health Perspect 2006;114:1677-1683.

13 Lee DH, Lee IK, Song K, Steffes M, Toscano W, Baker BA, Jacobs DR Jr: A strong doseresponse relation between serum concentrations of persistent organic pollutants and diabetes: results from the National Health and Examination Survey 1999-2002. Diabetes Care 2006;29:1638-1644.

14 Longnecker MP, Klebanoff MA, Brock JW, Zhou H: Polychlorinated biphenyl serum levels in pregnant subjects with diabetes. $\mathrm{Di}$ abetes Care 2001;24:1099-1101.

15 USEPA: The foundation for global action on persistent organic pollutants: a United States perspective. EPA/600/P-01/003F. Washington, US Environmental Protection Agency, Office of Research and Development, 2002.

16 Carpenter DO: Polychlorinated biphenyls (PCBs): routes of exposure and effects on human health. Rev Environ Health 2006;21:123.

17 Jones KC, de Voogt P: Persistent organic pollutants (POPs): state of the science. Environ Pollut 1999;100:209-221.

18 Kokotailo RA, Hill MD: Coding of stroke and stroke risk factors using international classification of diseases, revisions 9 and 10 . Stroke 2005;36:1776-1781.

19 Allen NB, Holford TR, Bracken MB, Goldstein LB, Howard G, Wang Y, Lichtman JH: Geographic variation in one-year recurrent ischemic stroke rates for elderly Medicare beneficiaries in the USA. Neuroepidemiology 2010;34:123-129.

20 Volkova N, McClellan W, Klein M, Flanders D, Kleinbaum D, Soucie JM, Presley R: Neighborhood poverty and racial differences in ESRD incidence. J Am Soc Nephrol 2008;19:356-364.

21 Cox AM, McKevitt C, Rudd AG, Wolfe CD: Socioeconomic status and stroke. Lancet Neurol 2006;5:181-188.

22 Huang X, Lessner L, Carpenter DO: Exposure to persistent organic pollutants and hypertensive disease. Environ Res 2006;102: 101-106.

23 Feigin VL, Lawes CM, Bennett DA, BarkerCollo SL, Parag V: Worldwide stroke incidence and early case fatality reported in 56 population-based studies: a systematic review. Lancet Neurol 2009;8:355-369.

24 Ali M, Atula S, Bath PM, Grotta J, Hacke W, Lyden P, Marler JR, Sacco RL, Lees KR: Stroke outcome in clinical trial patients deriving from different countries. Stroke 2009; 40:35-40.

25 Gaffney SH, Curriero FC, Strickland PT, Glass GE, Helzlsouer KJ, Breysse PN: Influence of geographic location in modeling blood pesticide levels in a community sur- rounding a US Environmental Protection Agency superfund site. Environ Health Perspect 2005;113:1712-1716.

26 Ketchum NS, Michalek JE: Postservice mortality of Air Force veterans occupationally exposed to herbicides during the Vietnam War: 20-year follow-up results. Mil Med 2005; 170:406-413.

27 Vena J, Boffetta P, Becher H, Benn T, Buenode-Mesquita HB, Coggon D, Colin D, FleschJanys D, Green L, Kauppinen T, Littorin M, Lynge E, Mathews JD, Neuberger M, Pearce N, Pesatori AC, Saracci R, Steenland K, Kogevinas $\mathrm{M}$ : Exposure to dioxin and nonneoplastic mortality in the expanded IARC international cohort study of phenoxy herbicide and chlorophenol production workers and sprayers. Environ Health Perspect 1998;106(suppl 2):645-653.

28 Hooiveld M, Heederik DJ, Kogevinas M, Boffetta P, Needham LL, Patterson DG Jr, Bueno-de-Mesquita HB: Second follow-up of a Dutch cohort occupationally exposed to phenoxy herbicides, chlorophenols, and contaminants. Am J Epidemiol 1998;147:891901.

29 Goncharov A, Haase RF, Santiago-Rivera A, Morse G, McCaffrey RJ, Rej R, Carpenter DO: High serum PCBs are associated with elevation of serum lipids and cardiovascular disease in a Native American population. Environ Res 2008;106:226-239.

30 Pelclova D, Fenclova Z, Preiss J, Prochazka B, Spacil J, Dubska Z, Okrouhlik B, Lukas E, Urban P: Lipid metabolism and neuropsychological follow-up study of workers exposed to 2,3,7,8-tetrachlordibenzo-p-dioxin. Int Arch Occup Environ Health 2002; 75(suppl):S60-S66.

-31 Matsusue K, Ishii Y, Ariyoshi N, Oguri K: A highly toxic PCB produces unusual changes in the fatty acid composition of rat liver. Toxicol Lett 1997;91:99-104.

32 Arzuaga X, Reiterer G, Majkova Z, Kilgore MW, Toborek M, Hennig B: PPAR-alpha ligands reduce $\mathrm{PCB}$-induced endothelial activation: possible interactions in inflammation and atherosclerosis. Cardiovasc Toxicol 2007;7:264-272.

33 Hennig B, Reiterer G, Majkova Z, Oesterling E, Meerarani P, Toborek M: Modification of environmental toxicity by nutrients: implications in atherosclerosis. Cardiovasc Toxicol 2005;5:153-160.

-34 Enan E, Matsumura F: 2,3,7,8-Tetrachlorodibenzo-p-dioxin (TCDD)-induced changes in glucose transporting activity in guinea pigs, mice, and rats in vivo and in vitro. J Biochem Toxicol 1994;9:97-106.

- 35 Kouznetsova M, Huang X, Ma J, Lessner L, Carpenter DO: Increased rate of hospitalization for diabetes and residential proximity of hazardous waste sites. Environ Health Perspect 2007;115:75-79. 